\title{
Temporal variability of larval growth, size, stage duration and recruitment of a wrasse, Coris julis (Pisces: Labridae), from the Azores
}

\author{
JORGE FONTES ${ }^{1}$, PEDRO AFONSO ${ }^{1}$, RICARDO S. SANTOS ${ }^{1}$ \\ and JENNIFER E. CASELLE ${ }^{2}$ \\ ${ }^{1}$ IMAR / Department of Oceanography and Fisheries, University of the Azores, PT: 9901-862 Horta, Portugal. \\ E-mail: fontes@uac.pt \\ ${ }^{2}$ Marine Science Institute, University of California Santa Barbara, CA 93106 USA
}

\begin{abstract}
SUMMARY: Temporal variability in the size at settlement (SAS), age at settlement (PLD), larval growth and recruitment patterns of a temperate wrasse, Coris julis, were examined over two recruitment seasons for a single island site from the Azores archipelago in the northeastern Atlantic. Relationships between these early life-history traits and recruitment variability over time were also investigated. Average PLD and SAS varied significantly among sampling dates over the settlement season, increasing consistently over time. This pattern was persistent over two consecutive summers. Larval growth was not a good predictor for PLD or SAS, which were in turn positively correlated with each other. Differences in recruitment magnitude over time were not related to SAS, PLD or larval growth. Instead, we found that recruits whose early pelagic stage (first $30 \mathrm{~d}$ ) overlapped part of a period of enhanced growth (above average and independent of larval age), tended to result in the largest recruitment events; these tended to occur in the mid season. Larvae from earlier and later settlement events, overlapping periods of depressed growth, were linked to more modest recruitment events. We hypothesize that short PLD, with resulting small SAS is favoured early in the season, when post-settlement density is lowest. Over the course of the settlement season, as recruits accumulate competition may increase, and larger SAS (associated with longer PLD), may provide a competitive/survival advantage.
\end{abstract}

Keywords: Coris julis, Azores, seasonal patterns, larval growth, recruitment.

RESUMEN: VARIABILIDAD TEMPORAL DEL CRECIMIENTO, TALLA Y DURACIÓN LARVARIA, Y RECLUTAMIENTO DE UN LÁBRIDO, CoRIS JUlis (PISCES: LABRIDAE), DE LAS Azores. - La variabilidad temporal en la talla de reclutamiento (SAS), edad de reclutamiento (PLD), crecimiento larvario y patrón de reclutamiento en un lábrido de aguas templadas, Coris julis, fueron examinados en dos épocas de reclutamiento consecutivas, en una isla de las Azores (Atlántico nordeste). Se examinaron también las relaciones entre estas características y la variabilidad de reclutamiento temporal. La PLD y la SAS medios aumentaron significativamente a lo largo del período de reclutamiento en los dos veranos consecutivos. La PLD y la SAS se correlacionaron positivamente, pero el crecimiento larvario no fue un buen predictor de estas características. Las diferencias en magnitud de reclutamiento entre fechas de muestreo sucesivas no fueron explicadas por las SAS/PLD medias, ni tampoco por el crecimiento larvario. En cambio, encontramos que los reclutas cuyos primeros estadios de desarrollo pelágico (30 días) se solapaban, en parte, con un periodo de crecimiento intenso (por encima del promedio e independiente de de edad) resultaron en los mayores reclutamientos; que tienden a suceder a mitad de la estación. Las larvas de asentamientos tempranos o tardíos (periodos de solapamiento, con crecimiento disminuido), se asociaron a reclutamientos modestos. Se plantea la hipótesis de que las PLD cortas, con las resultantes pequeñas SAS deberían ser favorecidas en la fase más temprana del período de reclutamiento, cuando la densidad de juveniles es menor. A lo largo del período de asentamiento, a medida que los reclutas se acumulan, la competición puede aumentar, y las mayores SAS (asociadas a mayores PLD), pueden proporcionar una ventaja competitiva o de supervivencia.

Palabras clave: Coris julis, Azores, patrón estacional, crecimiento larvario, reclutamiento. 


\section{INTRODUCTION}

Understanding the mechanisms linked to highly variable survival rates and recruitment in fish populations is one of the most important quests in fish biology and management and has major biological and economic implications (Carr and Syms, 2006). Early in the 20th century, Hjort (1914) suggested that larval mortality could determine recruitment variability. In particular, he hypothesized that year class size in temperate fishes was determined by larval feeding success at transition from yolk to exogenous feeding (critical period hypothesis). Since then, attempts to understand the population dynamics of temperate marine fishes have traditionally focused on growth and survivorship of early life history stages (Sponaugle and Pinkard, 2004a). This approach resulted from the generalized perception that, due to the high rates of mortality, combined with the great abundance of egg and early larval stages, small changes in larval mortality rates could lead to very large fluctuations in the numbers of fish becoming juveniles and adults, and that fast-growing fish have higher rates of survivorship than slow-growing fish of the same age (Anderson, 1988). Over the last two decades, many studies have gathered evidence to support this idea that lower growth rates during the larval and juvenile stages result in higher mortality (e.g. Healey, 1982; Campana, 1996; Meekan and Fortier, 1996; Hare and Cowen, 1997; Bergenius et al., 2002; Wilson and Meekan, 2002). Although recent theories highlight growth per se as a factor determining larval survival in plankton (Takasuka et al., 2003, 2004; Fuiman et al., 2005), a more parsimonious view places greater emphasis on larval size as a factor in predation vulnerability and on growth rate as a controller of cumulative size-dependent predation mortality (but see Fuiman et al., 2005). This view is based on the premise that larger individuals are less vulnerable to predation and thus more likely to survive than smaller individuals, which is the basis of Anderson's (1988) general "growth-mortality" hypothesis. Additionally, Houde (1987) proposed that fast growth should also increase survivorship by shortening the highly vulnerable pelagic larval stage (the "stage duration" hypothesis). This idea postulates that the probability of lethal events (predation and starvation) occurring throughout the pelagic stage is cumulative and increases with stage duration, so cohorts spending less time in the plankton should produce strong recruitment events (Leggett and Deblois, 1994).

There are however, potential trade-offs between the larval and juvenile life history stages (Sponaugle and Pinkard, 2004b). Due to high predation on the youngest recruits (e.g. Steele and Forrester, 2002a; Webster, 2002), larval traits at settlement (such as body size and condition) may influence initial survival on the reef, and potentially propagate to older juveniles (e.g. Hamilton et al., 2008). For example, size differences at settlement may be perpetuated into the juvenile period (Forrester, 1990). This is potentially important for fishes with size-dominated social hierarchies, as size may determine competitive abilities in obtaining food, space, and ultimately reproductive success (e.g. Oliveira et al., 2000). Investigation of natural variability of larval traits at settlement will contribute to our understanding of events occurring in the pelagic larval phase, of the impact of these events and processes on subsequent juvenile traits and, ultimately, of population dynamics (Searcy and Sponaugle, 2000). While several studies have elated variation in the growth rate, planktonic duration, condition and developmental state of fish larvae to settlement or recruitment variability (Searcy and Sponaugle, 2001; Macpherson and Raventos, 2006; Hamilton et al., 2008), few have related body size and survival to actual settlement dates. The temporal dimension within a recruitment season may result in a wide range of potential growth opportunities, and may be important to understanding recruitment and year-class strength of temperate fish populations (Cargnelli and Gross, 1996).

This study examined temporal variation in a number of early life history traits of recruits of the common Azorean wrasse, Coris julis, sampled over time in two consecutive summers, and relationships with recruitment magnitude. Specifically, we investigated the relationships among seasonal patterns of larval growth, larval stage duration, size at settlement, and recruitment variation.

\section{MATERIAL AND METHODS}

\section{Study area and species}

Varadouro bay is located on the southwest shore of Faial island $\left(38^{\circ} \mathrm{N}, 28^{\circ} \mathrm{W}\right)$, one of nine volcanic islands in the Azores archipelago (northeastern Atlantic) (Fig. 1). The shore along the Varadouro area is typical of Faial Island, with a limited shallow habitat, mostly composed of boulders of variable size and some open sand patches below $20 \mathrm{~m}$ (Tempera, 2008). The Varadouro bay is approximately 4 miles across. The Mediterranean rainbow wrasse, Coris julis (Linnaeus 1758; Pisces: Labridae), is a small, temperate, moderately short-lived (average 2 to 4 years) shallow-water reef fish, and one of the most abundant species in the Azorean reef fish community (Patzner and Santos, 1993; Afonso, 2002).

The rainbow wrasse spawns in the water column, releasing planktonic larvae, with a long pelagic larval dispersal stage (up to 46 days, Raventos and Macpherson, 2001, personal observation). Upon settlement, $C$. julis undergoes metamorphosis for about 4 days, as indicated by a metamorphic band visible on the otoliths (Raventos and Macpherson, 2001, personal observation) (Fig. 2). Spawning is seasonal in the Azores, occurring during the summer months (Afonso and Morato, unpublished data), as has been reported for the same species in the Mediterranean (Brusle, 1987; Gordoa et al., 2000). 


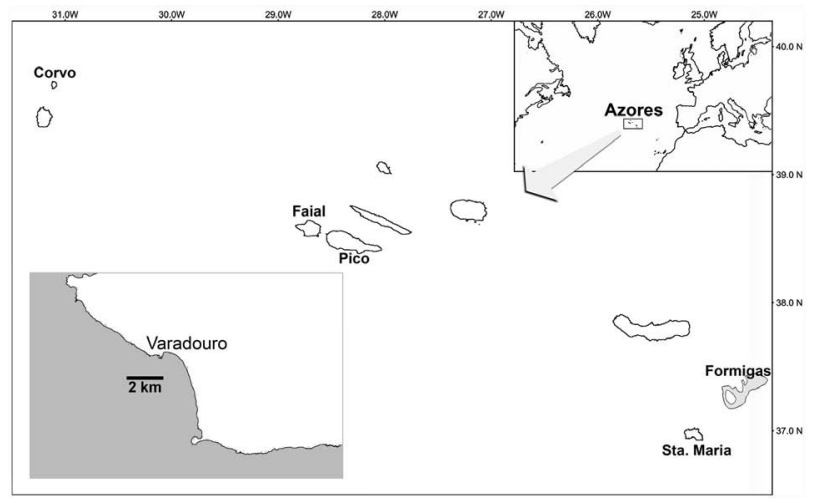

Fig. 1.- Map of Azores Archipelago (NE Atlantic) showing detail for Faial island and location of Varadouro.

\section{Recruitment surveys}

Recruitment surveys were performed on four fixed $20 \times 1 \mathrm{~m}$ transects, located in a boulder habitat at an average depth of $10 \mathrm{~m}$ in both years. All transects were placed in the most abundant habitat, boulders covered with coralline and turf algae (Tempera, 2008), to control for habitat differences and potentially avoid the confounding effect of habitat choice at settlement. A total of 44 transect surveys were performed and 1094 recruits were recorded. All recruit counts were conducted by the same diver, swimming at a constant slow speed along the transect, counting all recruits in the 20 $\mathrm{m}^{2}$ area. Recruits of all sizes were counted, although in this study we only considered very recently settled recruits, those less than one week old post-settlement. Age-size estimates were based on previous work that described age-length relationship for $C$. julis recruits (Fontes et al., 2009). Surveys were performed every two weeks, from mid-July to early November.

\section{Collections and otolith analysis}

Recruits were collected in each survey by divers using aquarium dip nets and kept in a fine mesh bag until they were stored in 50-ml plastic jars with $96 \%$ ethanol upon arrival on the boat. Recruits were collected at least $50 \mathrm{~m}$ away from permanent transects. In the laboratory, standard length of each recruit was measured to the nearest $0.1 \mathrm{~mm}$, and sagittal otoliths were dissected. The right otolith was stored in microplate wells submerged in medium-viscosity immersion oil for no less than 2 weeks to enhance ring clarity. We then removed excess oil from all otoliths before embedding them in thermoplastic resin and mounting them on glass slides. Embedded otoliths were later polished using $(9 \mu \mathrm{m})$ diamond microfilm.

\section{Otolith microstructure}

We found a strong linear relationship between sagittal radius and standard length of $C$. julis recruits ranging from newly settled to over one month old

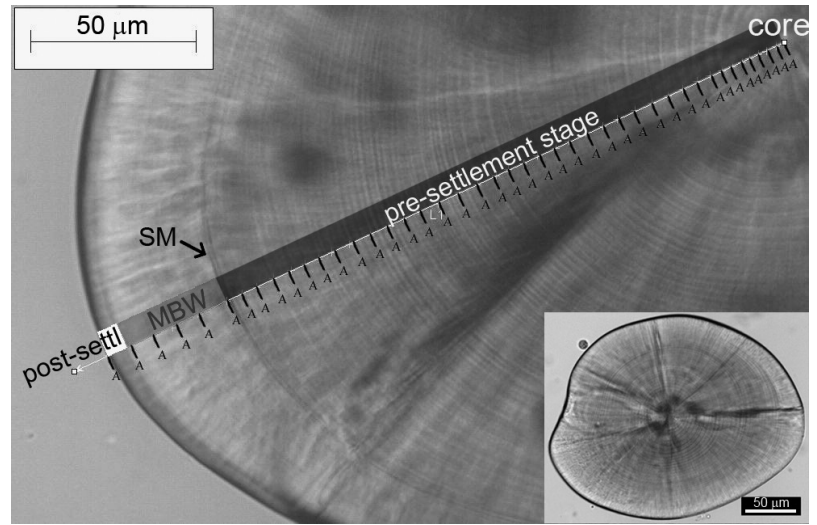

FIG. 2. -Sagitta from Coris julis recruits collected in the Azores. Black tick marks indicate daily increments. $\mathrm{MBW}=$ Metamorphic band width and post-settl = Otolith material deposited after emergence. SM indicates the otolith settlement mark.

$\left(\mathrm{r}^{2}=0,87 ; P<0.0001, \mathrm{n}=637\right)$. We therefore used otolith measurements as a relative measure of fish size and growth rates.

Otolith daily increments were counted and measured along the longest axis of the otolith, from core to outer edge (Fig. 2), using transmitted light microscopy, a video camera connected to a PC and the ImagePro 4.5 Image analysis tool kit. Otoliths were read once by a single reader after calibration by repeatedly reading a random set of 30 otoliths until the difference between counts was less than $10 \%$.

\section{Larval growth, SAS and PLD}

We randomly selected and analyzed the microstructure and early life history traits of 15 to 30 otoliths from recently settled recruits collected during each survey. Larval growth rates from hatch to settlement were calculated by averaging the daily increment widths observed on the pre-settlement portion of the otolith (Fig. 2). The mean PLD of the analyzed $C$. julis recruits pooled from 2005 and 2006 was $34 \pm 3.8$ days. The average larval age minus the standard deviation was chosen as the cut-off point ( $30 \mathrm{~d}$ ), for growth comparisons that encompassed larval growth from hatch to an age common to most individuals. Averaging the first 30 daily increments gives us a measure of growth from hatch to age 30 days. Otolith radius from core to settlement mark was used as a proxy for size at settlement (SAS), and PLD was given by the number of daily increments from the core to the settlement mark (Fig. 2).

\section{Growth at date}

Larval $C$. julis otolith increment widths typically increase with larval age. Increments increase rapidly during the first 15 to 20 days after hatching, at which point they tend to a plateau, that is, post hatch increments are always smaller than late stage increments (personal observation). Thus, in order to compare larval growth rates on a particular date between individuals 


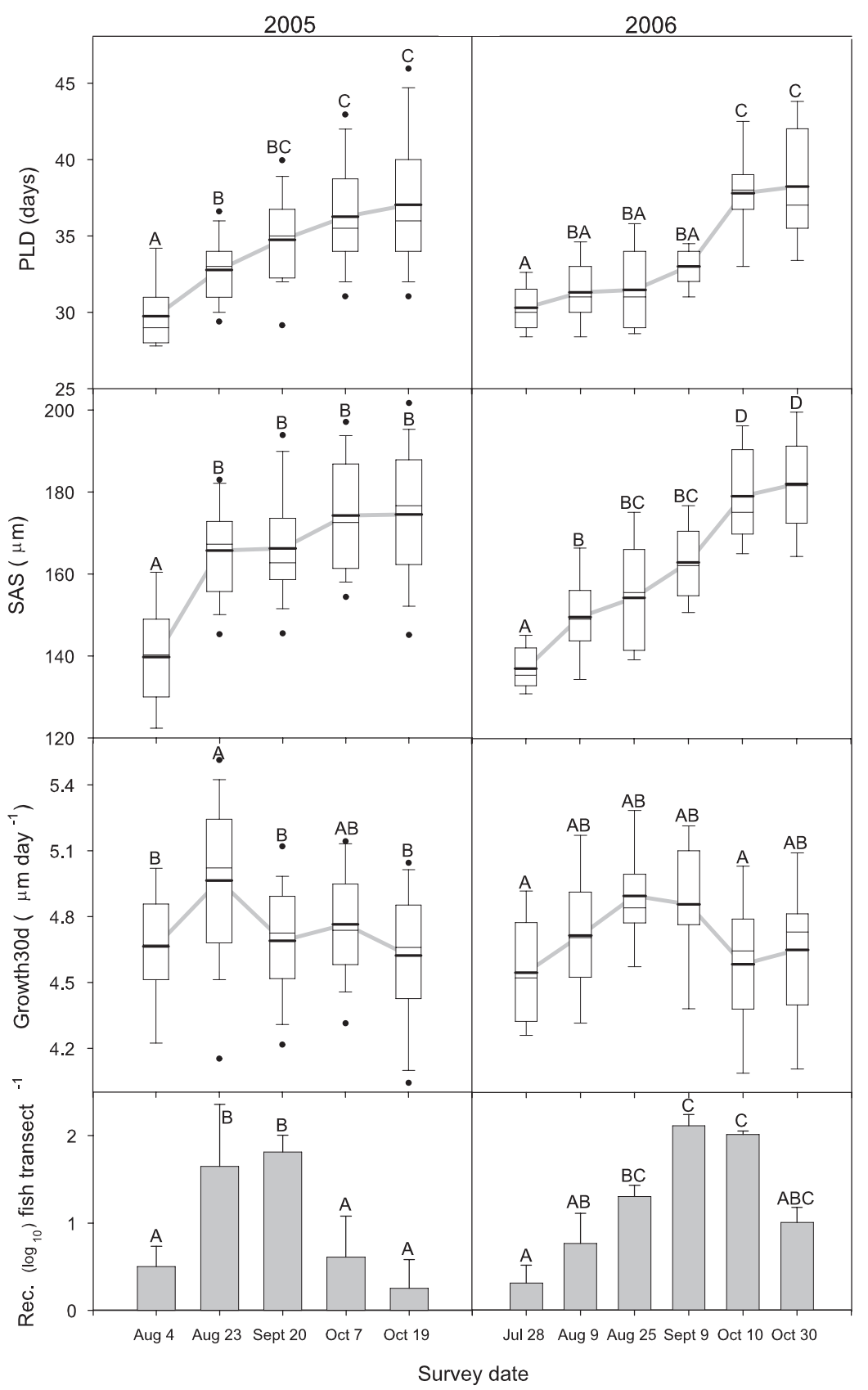

FIG. 3. -Temporal variation of Pelagic Larval Duration (PLD), Size at Settlement (SAS), average larval growth over 30 days post hatch (Growth) for Coris julis. Bars represent recruitment magnitude \pm SE. Bars or boxes not sharing letters are significantly different (Tukey HSD post hoc comparison).

with different hatch dates, it was necessary to remove this age effect from the absolute growth measurements. This was achieved by calculating the mean otolith increment width for each larval age, ranging from 1 to 30 days, from all sampling dates in each season. This overall mean for each age was used to calculate individual daily growth residuals at each age (1 to 30 days) (i.e. how much each individual at each age diverged from the mean of all individuals for that age). Individual back-calculated hatch dates were used to assign a
Julian date to each growth residual, and residuals were then averaged by date. For example, the growth residuals at age $10 \mathrm{~d}$ and $25 \mathrm{~d}$ from two individuals (different sampling dates) were grouped under the same date if the first one hatched 15 days after the latter. Positive averaged residuals for any given date indicate faster than average growth independent of age, and vice versa. The average growth at date residuals were plotted along a Julian date axis and compared with recruitment magnitude measured at different survey times. Prior to 
analysis, datasets of individual increment widths were lumped into 3-day bins to accommodate the possibility of aging errors up to 2 days.

\section{Water temperature}

Water temperature was measured 10 miles to the east of Varadouro with a moored (25 m depth) temperature logger (StowAway® tidbit).

\section{Statistical analysis}

The relationship between recruitment magnitude and early life history traits was examined in both years by computing linear regressions of recruitment against larval growth, size at age, SAS and PLD. We followed the procedure of Bergenius et al. (2002) to compare growth during 5-day bins within the first 30d of the larval phase. Differences between sampling dates in SAS, PLD, larval growth, larval growth $30 \mathrm{~d}$ and recruitment were tested using one-way ANOVA.

Recruit densities (fish/transect) were $\log 10(\mathrm{x}+0.1)$ transformed to conform to the assumptions of normality and deal with zeros in the data set, while average daily larval growth (larval growth), size at age, SAS (size at settlement) and PLD (pelagic larval duration) were $\log 10$ transformed (Quinn and Keough, 2002).

All statistical analyses were done using JMP 7.0 statistical analysis software.

\section{RESULTS}

Planktonic larval duration ranged from $27 \mathrm{~d}$ to 46 $\mathrm{d}$ in 2005 , and from $28 \mathrm{~d}$ to $45 \mathrm{~d}$ in 2006 . Within each year, the average PLD varied significantly among sampling dates (Table 1), ranging from $29.7( \pm 2.1)$ days to $37.1( \pm 4.2)$ days in 2005 and from $30.3( \pm 1.4)$ days to $38.2( \pm 3.5)$ days in 2006 . Average otolith radius at settlement (proxy for SAS), ranged from $139.8( \pm 12.7)$ $\mu \mathrm{m}$ to $174.5( \pm 15.3) \mu \mathrm{m}$ in 2005 , and $137.3( \pm 5.1) \mu \mathrm{m}$ to $182.1( \pm 15.3) \mu \mathrm{m}$ (Fig. 3), and overall differences between sampling dates were significant (Table 1). Both traits increased consistently over the course of the recruitment seasons (Fig. 3).

We found significant differences in larval growth measured for the entire larval stage ('Growth') and for the first 30 days in the plankton ('Growth 30 d') (Table 1). However, the temporal pattern of 'growth $30 \mathrm{~d}$ ' was different from that of PLD and SAS and there was no indication of a consistent increase throughout the season in either year (Fig. 3). Recruitment magnitude was uncorrelated with variation over time of both SAS $\left(2005, \mathrm{r}^{2}=0.08, \mathrm{~F}=0.2, P>0.05 ; 2006, \mathrm{r}^{2}=0.44, \mathrm{~F}=3.9\right.$, $P>0.05)$ and PLD (2005, $\mathrm{r}^{2}=0.005, P>0.05 ; 2006$, $\left.\mathrm{r}^{2}=0.28, P>0.05\right)$.

Recruitment was highly seasonal, peaking in September. In 2005, recruitment magnitude was highest in the August 23 and September 20 surveys, but not significantly different between the two. The highest
TABLE 1. - Summary of ANOVA comparing early life history traits and recruitment of Coris julis spanning all sampling dates in two consecutive seasons, 2005 and 2006. n represents the total number of otoliths analyzed per season (first four rows) and number of recruitment surveys each year (last row)

\begin{tabular}{|c|c|c|c|c|c|c|}
\hline & \multicolumn{3}{|c|}{2005} & \multicolumn{3}{|c|}{2006} \\
\hline & $F$ & $P$ & $\mathrm{n}$ & $F$ & $P$ & $\mathrm{n}$ \\
\hline SAS & 24.15 & $<0.0001$ & 104 & 37.3 & $<0.0001$ & 82 \\
\hline PLD & 19.61 & $<0.0001$ & 104 & 27.98 & $<0.0001$ & 82 \\
\hline Growth & 7.35 & $<0.0001$ & 104 & 4.67 & 0.0009 & 82 \\
\hline Growth $30 \mathrm{~d}$ & 5.10 & 0.0008 & 104 & 3.68 & 0.0049 & 82 \\
\hline Recruitment & 8.67 & 0.0008 & 5 & 8.11 & 0.0004 & 6 \\
\hline
\end{tabular}

TABLE 2. - Summary of linear regressions between SAS (response variable) and Growth, Growth $30 \mathrm{~d}$ and PLD (predictive variables) from Coris julis recruits collected over two recruitment seasons at Varadouro (Faial Island).

\begin{tabular}{lcccccc}
\hline & \multicolumn{3}{c}{2005} & & \multicolumn{3}{c}{2006} \\
& $\mathrm{r}^{2}$ & $\mathrm{~F}$ & $P$ & $\mathrm{r}^{2}$ & $\mathrm{~F}$ & $P$ \\
\hline Growth & 0.04 & 4.7 & 0.03 & 0.09 & 8 & 0.005 \\
Growth 30 d & 0.006 & 0.7 & 0.4 & 0.0009 & 0.1 & 0.78 \\
PLD & 0.71 & 259.8 & $<0.0001$ & 0.76 & 264 & $<0.0001$ \\
\hline
\end{tabular}

recruitment in 2006 was observed on September 9 and October 10, which were significantly different from the first two surveys (Fig. 3).

Larval growth from hatch to settlement was a poor predictor of SAS in both years, explaining less than $10 \%$ of SAS variability, while growth during the first 30 days and SAS were uncorrelated. On the other hand, PLD was positively correlated with SAS in both seasons, explaining substantial variability of SAS $(71 \%$ and $76 \%$ in 2005 and 2006 respectively) (Table 2). Except for the recruits from the second sampling date in 2005 (August 23), which experienced relatively fast

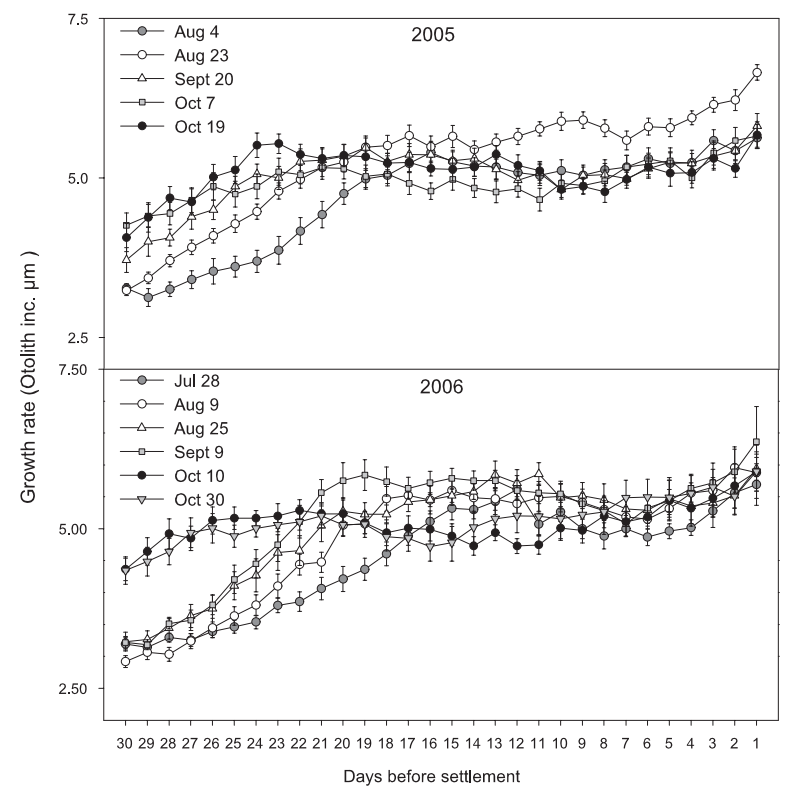

FIG. 4. - Average hindcast growth trajectories of Coris julis recruits sampled on each survey at Varadouro (Faial island). Mean values are shown \pm SE for 2005 and 2006 
TABLE 3. - Summary of linear regressions between Recruitment (response variable) and larval growth over 5-day intervals during the first 30 days in the plankton, between average growth during the first 30 days in plankton (Growth $30 \mathrm{~d}$ ) and between average growth from hatch to settlement (Growth) from Coris julis recruits collected over two recruitment seasons at Varadouro (Faial Island). Correction of $P$ values for multiple comparison are not present since all $P$ values are larger than 0.05 .

\begin{tabular}{|c|c|c|c|c|c|c|c|c|}
\hline Growth interval & 1 to 5 & 6 to 10 & 11 to 15 & 16 to 20 & 21 to 25 & 26 to 30 & Growth $30 \mathrm{~d}$ & Growth \\
\hline \multicolumn{9}{|l|}{2005} \\
\hline $\mathrm{r}^{2}$ & 0.07 & 0.07 & 0.02 & 0.51 & 0.37 & 0.07 & 0.37 & 0.48 \\
\hline $\mathrm{F}$ & 0.23 & 0.25 & 0.08 & 3.2 & 1.7 & 0.2 & 1.7 & 2.8 \\
\hline$P$ & 0.66 & 0.64 & 0.79 & 0.17 & 0.27 & 0.65 & 0.27 & 0.19 \\
\hline $\begin{array}{l}2000 \\
\mathrm{r}^{2}\end{array}$ & 0.1 & 0.18 & 0.54 & 0.3 & 0.09 & 0.05 & 0.2 & 0.55 \\
\hline $\mathrm{F}$ & 0.5 & 0.9 & 4.8 & 1.7 & 0.4 & 0.2 & 1.1 & 5.1 \\
\hline$P$ & 0.5 & 0.39 & 0.09 & 0.25 & 0.55 & 0.65 & 0.37 & 0.09 \\
\hline
\end{tabular}
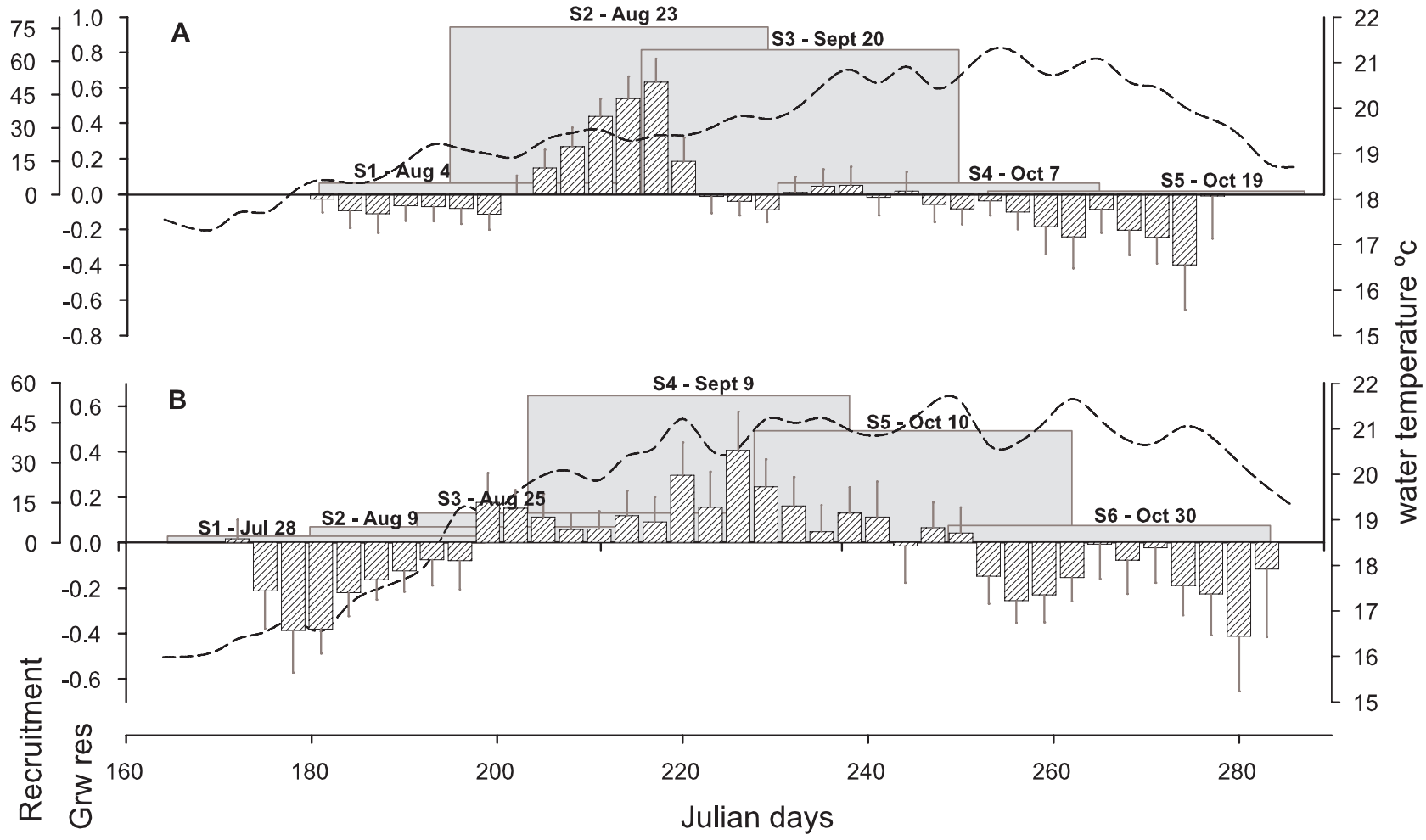

FIG. 5. - Coris julis larval average daily growth residuals at date during first 30 days in the plankton. The height of gray boxes is proportional to recruit magnitude measured each survey, in number of fish / transect (short left axis). The box widths span 30 days on the xx axis. The left side of each box is placed on the modal hatch date of recruits collected on that survey. The dashed line represents daily average water temperature at $25 \mathrm{~m}$. Panel $\mathrm{A}=2005$ and panel $\mathrm{B}=2006$. Abbreviations, Grw res - Growth residuals. See text for calculation of growth residuals.

growth just prior to settlement, there was no obvious divergence of pre-settlement growth trajectories among recruits from different dates for either year (Fig. 4).

Neither larval growth over the first 30 days in the plankton nor larval growth during the entire larval stage were good predictors of the recruitment magnitude observed in the two seasons. Similarly, we found no relationships between recruitment and larval growth during any of the 5-day bins analyzed from hatch to age $30 \mathrm{~d}$ (Table 3 ). Alternatively, we found that positive growth residuals (growth independent of age) were most frequent between Julian date 200 and 250, that is, from late August to early October. In 2005, most of the post-hatch life of recruits from the second survey (August 23) overlapped this period of large positive growth anomalies (Fig. 5). The early post-hatch period of recruits collected on the following survey, September 20 (the second highest recruitment magnitude), was also coincident with this enhanced growth period. Most of these recruit's subsequent larval stage overlapped a period of intermediate growth rates (growth residuals close to zero). All or most of the first $30 \mathrm{~d}$ in the plankton of recruits collected on August 4, October 7 and October 19 were coincident with periods of lower growth. In particular, the days following the median hatch date of these recruits overlapped periods of slower than average growth.

In 2006, we observed a similar trend, that is, the most abundant recruitment pulses tended to be composed of recruits whose larval stage overlapped periods 
of enhanced growth. The two strongest recruitment events were observed on September 9 and October 10 (surveys 4 and 5). On average, most of the larval stage (up to 30 days) of these recruits, overlapped the period of fastest growth (Fig. 5). Recruit density on survey 3 (August 25) was intermediate although the corresponding 30-day larval growth period mostly overlapped positive growth residuals, except for the first week post-hatch. The first two and the last surveys, when recruitment was very low, were associated with periods of negative growth residuals.

Water temperature (3-day averages) and larval growth residuals were not correlated in $2005(\mathrm{~F}=2.1$, $P>0.05)$, but in 2006 water temperature explained $17 \%$ of growth residuals variability $(\mathrm{F}=7.79, P<0.05)$, corresponding to the coincident increase in both variables during the first half of the recruitment season. During the second half, growth residuals declined faster than water temperature.

\section{DISCUSSION}

The variability in early life-history traits for the one location in this study was within the range previously observed over broad spatial (along the archipelago) and temporal (over 5 years) scales in the Azores (personal observation). It was surprising to note that both average SAS and PLD consistently increased throughout both seasons, independently of larval growth, that is, larger SAS resulted from longer larval stages rather than faster growth rates.

Even though there is general agreement that early life history can impact population dynamics of marine fishes during the transition between larval and juvenile stages (Hoey and McCormick, 2004), few studies have investigated the temporal variation of early life-history traits of successive cohorts of settlers entering a local population (McCormick, 1994; Searcy and Sponaugle, 2001; Sponaugle and Grorud-Covert, 2006), and fewer have related early traits and survival to settlement or birth date (e.g. Cargnelli and Gross, 1996). While most workers have found age at settlement to be more variable than size, some have also reported increasing SAS over the recruitment season (Searcy and Sponaugle, 2000). For example Fowler and Short (1996) reported consecutive increases in SAS and PLD during the first phase of the recruitment season of King George whiting, Sillaginodes punctata, while second phase settlers were about the same size at settlement despite having significantly longer PLD. The authors argued that in the second phase slower-growing larvae increased their PLD in order to achieve some hypothetical critical size before settling.

The consistent increase in SAS and PLD among sampling dates observed in our study was not directly related to variable larval growth over time, which is likely to reflect food availability and temperature regimes (Sponaugle et al., 2006; Sponaugle and GrorudCovert, 2006). Cowen and Sponaugle (1997) argued that PLD (which was strongly correlated with SAS in our study) may be determined by a tradeoff between settling rapidly in order to initiate higher growth rates as juveniles, versus extending the larval stage beyond competency to settle in order to maximize chances of settling under optimal conditions (e.g. lower predation or lower current speeds, Sponaugle \& Cowen, 1994). While short PLD should reduce larval mortality (Leggett and Deblois, 1994), larvae spending longer periods in the plankton tend to settle at larger sizes (Denit and Sponaugle, 2004), as it may be advantageous for escaping predators and competing for resources (Tupper and Boutilier, 1995; McCormick, 1999). For example, Steele and Forrester (2002b) showed that small blackeye gobies are more vulnerable to the sublethal effects (reduced growth) of intraspecific competition, whereas large gobies grow more rapidly than small conspecifics at progressively higher densities throughout the recruitment season. Given these various tradeoffs, we suggest that early in the settlement season in our study, when settler density is low, it might "pay off" to settle at the youngest possible age, reducing larval mortality, since the resulting small SAS may be compensated by faster juvenile growth under low intraspecific competition. Conversely, later in the season, when recruit density is higher, "risking" a longer pelagic stage to settle at larger size is likely to favour post-settlement competition, leading to higher growth and survival. In addition, if predators differentially consume smaller juveniles, settling at larger sizes among older cohorts (larger post-settlers) may reduce the effects of sizebased predation.

Such a mechanism assumes that $C$. julis have the ability to delay metamorphosis or extend the pelagic stage, which has not yet been described. Delayed metamorphosis is usually associated with a drop in presettlement growth (McCormick, 1999), which was not the case in this study, as late pre-settlement growth was very similar for all recruit samples (except the August 23 sample from 2005). Here we found that $C$. julis was able to extend the pelagic stage while sustaining reasonable growth. Given the lack of correlation between PLD, SAS and growth or temperature, we suggest that size and age at settlement could result from maternal effects (Green and McCormick, 2005). It has been shown that maternal investment may be environmentally sensitive, as females may allocate resources to their offspring according to environmental conditions (McCormick, 2006; Green and Chambers, 2007).

In a study of a bluegills population, Cargnelli and Gross (1996), showed that cohorts produced early in the season had disproportionally higher relative survivorship than subsequent cohorts, as they were able to achieve larger body size before winter. Our study was not designed to test the demographic consequences of a consistent increase in SAS over time, but $C$. julis recruiting at different times may make different contributions to the yearling population (fish surviving to the next season). It would be interesting to address 
this issue in future work as it would allow us to better understand and predict the consequences of temporal variable recruitment patterns on population structure.

Coris julis growth and recruitment magnitude has been shown to be positively correlated over a wide spatial range, around the Azores islands, where sampling locations were widely spaced and larvae probably experienced different environmental conditions (Fontes, 2009). In the present study, however, planktonic stages of recruits sampled successively partially overlap in time and possibly in space, that is, we removed most of the potential for spatial variability and investigated the temporal component. Thus, rather than making a direct comparison of average larval growth and recruitment magnitude for each sampling date, by identifying dates of enhanced growth (independent of larval age or settlement date) we were able to establish that recruits (samples) whose first 30 days in the plankton overlapped all or part of the dates with enhanced growth tended to result in strong recruitment events.

The idea that growth during a fraction of the larval period is the main determinant of survival of marine fishes is not novel (Leggett and Deblois, 1994; Bergenius et al., 2002). Previous workers have recognized variation in growth rate and have related it to the variation in environmental conditions (e.g. Sponaugle and Pinkard, 2004b; Sponaugle et al., 2006). In particular, water temperature can be an important determinant of larval history for both tropical and temperate species with warmer temperatures leading to faster growth rates (Green and Fisher, 2004; Sponaugle et al., 2006), shorter larval durations (McCormick and Molony, 1995; Green and Fisher, 2004; Sponaugle et al., 2006), and/or larger sizes-at-age (McCormick and Molony, 1995). However, this was not the case in our study, as temperature explained no or little variation in age-corrected growth. Nevertheless, growth must be sustained with adequate food, or higher metabolic rates associated with warmer water may increase susceptibility to starvation (Houde, 1989; Peck and Daewel, 2007). Stronger competition for food (Agnew et al., 2000), cannibalistic behaviour (Woods and Barkmann, 1995) and faster yolk absorption with lower conversion efficiency of yolk to tissues (Heming, 1982) may also be expected at high temperatures, when metabolism and energy requirements are higher. Given that water temperature by itself did not have an obvious impact on recruitment or growth, it is more likely that food availability caused the variation in growth and recruitment, as phytoplankton productivity has been shown to be positively related to fish recruitment magnitude (Biktashev et al., 2003). A positive correlation between lagged chlorophyll $a$ concentration in the Varadouro area and recruitment magnitude over three consecutive years was observed (J. Fontes, pers. comm.), further supporting this hypothesis. Nevertheless, the effects of temperature on phytoplankton productivity make it difficult to separate the influence of temperature and food availability (McCormick, 1994).
Finally, it remains largely unknown whether the same traits that favour recruitment also favour postsettlement survival, and how such relationships may vary over time or at different post-settlement densities. We propose that future research should be devoted to determining: (a whether the relative importance of size and condition-related early life traits for postsettlement selection (e.g. PLD, SAS and condition) are variable over time, and (b) whether traits that favour pre-settlement survival also, directly or indirectly, contribute to positive post-settlement selection.

\section{ACKOWLEDGEMENTS}

We sincerely thank A. Donay, F. Cardigos, J. Barr, R. Bettencourt, R. Ferraz, M. Sheehy, N. Serpa, S. Hamilton, and the crews of RV Arquipélago and RV Águas Vivas for helping with sample collections and laboratory work. For individual support, J. Fontes thanks FCT/MCTES (SFRH/BD/12788/2003 and FLAD). IMAR-DOP is UI\&D No. 531 funded through the Programmatic and Multiannual programs of FCT/ MCTES and Azorean DRCT, part FEDER. This paper is a contribution to MAREFISH (FCT-POCTI/ BSE/41207/2001) and MARMACII (INTERREG/05/ $\mathrm{MAC} / 4.2 / \mathrm{A} 4)$.

\section{REFERENCES}

Afonso, P. - 2002. Spatial patterns in the littoral fish community of the Azores. MS, Univ. Coimbra.

Agnew, D.J., S. Hill and J.R. Beddington. - 2000. Predicting the recruitment strength of an annual squid stock: Loligo gahi around the Falkland Islands. Can. J. Fish. Aquat. Sci., 57: 2479-2487.

Anderson, J.T. - 1988. A review of size dependent survival during pre-recruit stages of fishes in relation to recruitment. J. Northwest Atl. Fish. Sci., 8: 55-66.

Bergenius, M.A.J., M.G. Meekan, D.R. Robertson and M.I. McCormick. - 2002. Larval growth predicts the recruitment success of a coral reef fish. Oecologia. 131: 521-525.

Biktashev, V.N., J. Brindley and J.W. Horwood. - 2003. Phytoplankton blooms and fish recruitment rate. J. Plankton Res., 25: 21-33.

Brusle, S. - 1987. Sex-inversion of the hermaphroditic, protogymious teleost Coris julis L. (Labridae). J. Fish Biol., 30: 605-616.

Campana, S.E. - 1996. Year-class strength and growth rate in young Atlantic cod Gadus morhua. Mar. Ecol. Prog. Ser., 135: 21-26.

Cargnelli, L.M. and M.R. Gross. - 1996. The temporal dimension in fish recruitment: birth date, body size, and size-dependent survival in a sunfish (bluegill: Lepomis macrochirus). Can. J. Fish. Aquat. Sci., 53: 360-367.

Carr, M.H. and C. Syms. - 2006. Recruitment In: L.G. Allen, D.J. Pondella and M. Horn (eds.), The ecology of marine fishes: California and adjacent waters, pp. 411-427 University of California Press, Berkeley.

Cowen, R.K. and S. Sponaugle. - 1997. Relationship between early life history traits and recruitment among coral reef fishes. In: R.C. Chambers and E.A. Trippel (eds.), Early life history and recruitment in fish populations, pp. 423-449. Chapman \& Hall, New York.

Denit, K. and S. Sponaugle. - 2004. Growth variation, settlement, and spawning of gray snapper across a latitudinal gradient. Trans. Am. Fish. Soc., 133: 1339-1355.

Fontes, J. - 2009. Larval dispersal and recruitment patterns in Azorean coastal fishes - Implications for Marine Reserves. PhD, Univ. Azores.

Fontes, J., J.E. Caselle, P. Afonso and R.S. Santos. - 2009. Multiscale recruitment patterns and effects on local population size of 
a temperate reef fish. J. Fish Biol., 75: 1271-1286.

Forrester, G.E. - 1990. Factors influencing the juvenile demography of a coral-reef fish. Ecology. 71: 1666-1681.

Fowler, A.J. and D.A. Short. - 1996. Temporal Variation in the Early Life-history Characteristics of the King George Whiting (Sillaginodes punctata) from Analysis of Otolith Microstructure. Mar. Freshwater Res., 47: 809-818.

Fuiman, L.A., J.H. Cowan, M.E. Smith and J.P. O’Neal. - 2005. Behavior and recruitment success in fish larvae: variation with growth rate and the batch effect. Can. J. Fish. Aquat. Sci., 62: $1337-1349$.

Gordoa, A., B. Moli and N. Raventos. - 2000. Growth performance of four wrasse species on the north-western Mediterranean coast. Fisheries Research. 45: 43-50.

Green, B.S. and R.C. Chambers. - 2007. Maternal effects vary between source populations in the Atlantic tomcod Microgadus tomcod. Mar. Ecol. Prog. Ser., 344: 185-195.

Green, B.S. and R. Fisher. - 2004. Temperature influences swimming speed, growth and larval duration in coral reef fish larvae. J. Exp. Mar. Biol. Ecol., 299: 115-132.

Green, B.S. and M.I. McCormick. - 2005. Maternal and paternal effects determine size, growth and performance in larvae of a tropical reef fish. Mar. Ecol. Prog. Ser., 289: 263-272.

Hamilton, S.L., J. Regetz and R.R. Warner. - 2008. Postsettlement survival linked to larval life in a marine fish. Proc. Natl. Acad. Sci. USA. 105: 1561-1566.

Hare, J.A. and R.K. Cowen. - 1997. Size, growth, development, and survival of the planktonic larvae of Pomatomus saltatrix (Pisces: Pomatomidae). Ecology, 78: 2415-2431.

Healey, M.C. - 1982. Timing and relative intensity of size-selective mortality of juvenile chum salmon (Oncorhynchus keta) during early sea life. Can. J. Fish. Aquat. Sci., 39: 952-957.

Heming, T.A. - 1982. Effects of temperature on utilisation of yolk by chinook salmon (Oncorhynchus tshawytscha) eggs and alevins. Can. J. Fish. Aquat. Sci., 39: 184-190.

Hjort, J. - 1914. Fluctuations in the great fisheries of Northern Europe. Rapport et Procès-Verbaux des Réunions du Conseil Permanent International pour l'Exploration de la Mer. 20: 1-13.

Hoey, A.S. and M.I. McCormick. - 2004. Selective predation for low body condition at the larval-juvenile transition of a coral reef fish. Oecologia. 139: 23-29.

Houde, E.D. - 1987. Fish early life dynamics and recruitment variability. Am. Fish. Soc. Symp., 2: 17-29.

Houde, E.D. - 1989. Comparative growth, mortality, and energetics of marine fish larvae - temperature and implied latitudinal effects. Fish. Bull., 87: 471-495.

Leggett, W.C. and E. Deblois. - 1994. Recruitment in marine fishes - is it regulated by starvation and predation in the egg and larval stages. Neth J Sea Res. 32: 119-134.

Macpherson, E. and N. Raventos. - 2006. Settlement patterns and post-settlement survival in two Mediterranean littoral fishes: influences of early-life traits and environmental variables. Mar. Biol.: 167-177.

McCormick, M.I. - 1994. Variability in age and size at settlement of the tropical goatfish Upeneus tragula (Mullidae) in the northern Great Barrier Reef lagoon. Mar. Ecol. Prog. Ser., 103: 1-15.

McCormick, M.I. - 1999. Delayed metamorphosis of a tropical reef fish (Acanthurus triostegus): a field experiment. Mar. Ecol. Prog. Ser., 176: 25-38.

McCormick, M.I. - 2006. Mothers matter: Crowding leads to stressed mothers and smaller offspring in marine fish. Ecology, 87: 1104-1109.

McCormick, M.I. and B.W. Molony. - 1995. Influence of water temperature during the larval stage on size, age and body condition of a tropical reef fish at settlement. Mar. Ecol. Prog. Ser., 118: 59-68.

Meekan, M.G. and L. Fortier. - 1996. Selection for fast growth during the larval life of Atlantic cod Gadus morhua on the Scotian Shelf. Mar. Ecol. Prog. Ser., 137: 25-37.

Oliveira, R.F., J.A. Miranda, N. Carvalho, E.J. Goncalves, M.S.
Grober and R.S. Santos. - 2000. Male mating success in the Azorean rock-pool blenny: the effects of body size, male behaviour and nest characteristics. J. Fish Biol., 57: 1416-1428.

Patzner, R.A. and R.S. Santos. - 1993. Ecology of rocky littoral fishes of the Azores. Courrier Forschungsinstitut Senckenberg. 159: 423-427.

Peck, M.A. and U. Daewel. - 2007. Physiologically based limits to food consumption, and individual-based modeling of foraging and growth of larval fishes. Mar. Ecol. Prog. Ser., 347: 171-183.

Quinn, G.P. and M.J. Keough. - 2002. Experimental design and data analysis for biologists. Cambridge University Press, Cambridge.

Raventos, N. and E. Macpherson. - 2001. Planktonic larval duration and settlement marks on the otoliths of Mediterranean littoral fishes. Mar. Biol., 138: 1115-1120.

Searcy, S.P. and S. Sponaugle. - 2000. Variable larval growth in a coral reef fish. Mar. Ecol. Prog. Ser., 206: 213-226.

Searcy, S.P. and S. Sponaugle. - 2001. Selective mortality during the larval-juvenile transition in two coral reef fishes. Ecology. 82: $2452-2470$.

Sponaugle, S. and R.K. Cowen. - 1994. Larval durations and recruitment patterns of 2 caribbean gobies (Gobiidae) - contrasting early-life histories in demersal spawners. Mar. Biol., 120: 133-143.

Sponaugle, S., K. Grorud-Colvert and D. Pinkard. - 2006. Temperature-mediated variation in early life history traits and recruitment success of the coral reef fish Thalassoma bifasciatum in the Florida Keys. Mar. Ecol. Prog. Ser., 308: 1-15.

Sponaugle, S. and K. Grorud-Covert. - 2006. Environmental variability, early life-history traits, and survival of new coral reef fish recruits. Integr. Comp. Biol., 46: 623-633.

Sponaugle, S. and D. Pinkard. - 2004a. Lunar cyclic population replenishment of a coral reef fish: shifting patterns following oceanic events. Mar. Ecol. Prog. Ser., 267: 267-280.

Sponaugle, S. and D.R. Pinkard. - 2004b. Impact of variable pelagic environments on natural larval growth and recruitment of the reef fish Thalassoma bifasciatum. J. Fish Biol., 64: 34-54.

Steele, M.A. and G.E. Forrester. - 2002a. Early postsettlement predation on three reef fishes: effects on spatial patterns of recruitment. Ecology. 84: 1076-1091.

Steele, M.A. and G.E. Forrester. - 2002b. Variation in the relative importance of sublethal effects of predators and competitors on growth of a temperate reef fish. Mar. Ecol. Prog. Ser., 237: 233-245.

Takasuka, A., I. Aoki and I. Mitani. - 2003. Evidence of growthselective predation on larval Japanese anchovy Engraulis japonicus in Sagami Bay. Mar. Ecol. Prog. Ser., 252: 223-238.

Takasuka, A., I. Aoki and I. Mitani. - 2004. Three synergistic growth-related mechanisms in the short-term survival of larval Japanese anchovy Engraulis japonicus in Sagami Bay. Mar. Ecol. Prog. Ser., 270: 217-228.

Tempera, F. - 2008. Benthic habitats of the extended Faial island shelf and their relationship to geologic, oceanographic and infralittoral biologic features. PhD thesis, Univ. Saint Andrews.

Tupper, M. and R.G. Boutilier. - 1995. Effects of conspecific density on settlement, growth and post-settlement survival of a temperate reef fish. J. Exp. Mar. Biol. Ecol., 191: 209-222.

Webster, M.S. - 2002. Role of predators in the early post-settlement demography of coral-reef fishes. Oecologia. 131: 52-60.

Wilson, D.T. and M.G. Meekan. - 2002. Growth-related advantages for survival to the point of replenishment in the coral reef fish Stegastes partitus (Pomacentridae). Mar. Ecol. Prog. Ser., 231: 247-260.

Woods, J.D. and W. Barkmann. - 1995. Modeling oligotrophic zooplankton production - seasonal oligotrophy off the Azores. ICES J. Mar. Sci., 52: 723-734.

Scient. ed.: E. Macpherson

Received July 7, 2009. Accepted February 25, 2010.

Published online August 16, 2010. 